\title{
An Optogenetic Approach for Investigation of Excitatory and Inhibitory Network GABA Actions in Mice Expressing Channelrhodopsin-2 in GABAergic Neurons
}

\author{
Guzel Valeeva, ${ }^{1,2,3}$ Thomas Tressard, ${ }^{1,2}$ Marat Mukhtarov, ${ }^{3}$ Agnes Baude, ${ }^{1,2}$ and Rustem Khazipov ${ }^{1,2,3}$ \\ ${ }^{1}$ Institut de Neurobiologie de la Méditerranée, Institut National de la Santé et de la Recherche Médicale U-901, 13273 Marseille, France, ${ }^{2}$ Aix-Marseille \\ University, 13273 Marseille, France, and ${ }^{3}$ Laboratory of Neurobiology, Kazan Federal University, 420008 Kazan, Russia
}

To investigate excitatory and inhibitory GABA actions in cortical neuronal networks, we present a novel optogenetic approach using a mouse knock-in line with conditional expression of channelrhodopsin-2 (ChR2) in GABAergic interneurons. During whole-cell recordings from hippocampal and neocortical slices from postnatal day $(\mathrm{P}) 2-\mathrm{P} 15$ mice, photostimulation caused depolarization and excitation of interneurons and evoked barrages of postsynaptic GABAergic currents. Excitatory/inhibitory GABA actions on pyramidal cells were assessed by monitoring the alteration in the frequency of EPSCs during photostimulation of interneurons. We found that in slices from P2-P8 mice, photostimulation evoked an increase in EPSC frequency, whereas in P9-P15 mice the response switched to a reduction in EPSC frequency, indicating a developmental excitatory-to-inhibitory switch in GABA actions on glutamatergic neurons. Using a similar approach in urethane-anesthetized animals in vivo, we found that photostimulation of interneurons reduces EPSC frequency at ages P3-P9. Thus, expression of ChR2 in GABAergic interneurons of mice enables selective photostimulation of interneurons during the early postnatal period, and these mice display a developmental excitatory-to-inhibitory switch in GABA action in cortical slices in vitro, but so far show mainly inhibitory GABA actions on spontaneous EPSCs in the immature hippocampus and neocortex in vivo.

Key words: ChR2; cortex; GABA; hippocampus; inhibition; interneurons; patch clamp; optogenetics

Significance Statement

We report a novel optogenetic approach for investigating excitatory and inhibitory GABA actions in mice with conditional expression of channelrhodopsin-2 in GABAergic interneurons. This approach shows a developmental excitatory-to-inhibitory switch in the actions of GABA on glutamatergic neurons in neocortical and hippocampal slices from neonatal mouse pups in vitro, but also reveals inhibitory GABA actions in the neonatal mouse neocortex and hippocampus in vivo.

\section{Introduction}

GABA is the main inhibitory neurotransmitter in the adult brain (Krnjevic and Phillis, 1963; Curtis et al., 1970; Freund and Buz-

\footnotetext{
Received Sept. 17, 2015; revised March 19, 2016; accepted April 12, 2016.

Author contributions: R.K. designed research; G.V., T.T., M.M., A.B., and R.K. performed research; G.V. and T.T. analyzed data; G.V. and R.K. wrote the paper.

This work was supported by the Institut National de la Santé et de la Recherche Médicale (Laboratoire International Associé to R.K.), a Grant to Leading Scientists (11.G34.31.0075 to R.K.), the Program of Competitive Growth of Kazan Federal University, a subsidy allocated to Kazan Federal University for the state assignment in the sphere of scientific activities, and the Russian Foundation for Basic Research (Grant\#14-04-01457 to M.M.). We thank Dr. Gero Miesenböck and Dennis Kätzel for providing Gad2::CreER-R26ChR2-EGFP mice and Drs. Rosa Cossart and Alfonso Represa for helpful discussions and comments on the manuscript.

The authors declare no competing financial interests.

Correspondence should be addressed to either of the following: Dr. Roustem Khazipov, INMED/INSERM U901, 134 avenue de Luminy BP13, 13273 Marseille, France. E-mail: roustem.khazipov@inserm.fr; or Dr. Guzel Valeeva, Laboratory of Neurobiology, Kazan Federal University, 18 Kremlevskaya St., 420008 Kazan, Russia. E-mail: guzelvaleyeva@yahoo.com.

DOI:10.1523/JNEUROSCI.3482-15.2016

Copyright $\odot 2016$ the authors $\quad 0270-6474 / 16 / 365961-13 \$ 15.00 / 0$
}

sáki, 1996; Farrant and Kaila, 2007). However, inhibitory GABA actions are not ubiquitous and in a number of cases GABA may also exert excitatory actions. These include excitatory actions of GABA (and glycine) on neurons at early developmental stages (Cherubini et al., 1991; Owens and Kriegstein, 2002; Ben Ari et al., 2007; Kaila et al., 2014b), depolarizing and excitatory actions of GABA in certain types of interneurons (Fu and Van den Pol, 2007) and in various cell compartments (Gulledge and Stuart, 2003; Szabadics et al., 2006; Romo-Parra et al., 2008; Tyzio et al., 2008), and acquisition of an excitatory GABA phenotype in neurons following trauma and in brain ischemia, epilepsy, and pain (van den Pol et al., 1996; Cohen et al., 2002; Nabekura et al., 2002; Khalilov et al., 2003; Price et al., 2009; Kaila et al., 2014a,b). Actions of GABA may critically depend on the network state (Woodruff et al., 2011; Khalilov et al., 2015) and they are also subject to hormonal modulation, e.g., by oxytocin (Tyzio et al., 2006; Mazzuca et al., 2011) or neuroactive steroids (Dine et al., 2014). Hence there is a necessity for research tools for the assess- 
A

Gad2::CreER-R26ChR2-EGFP mouse
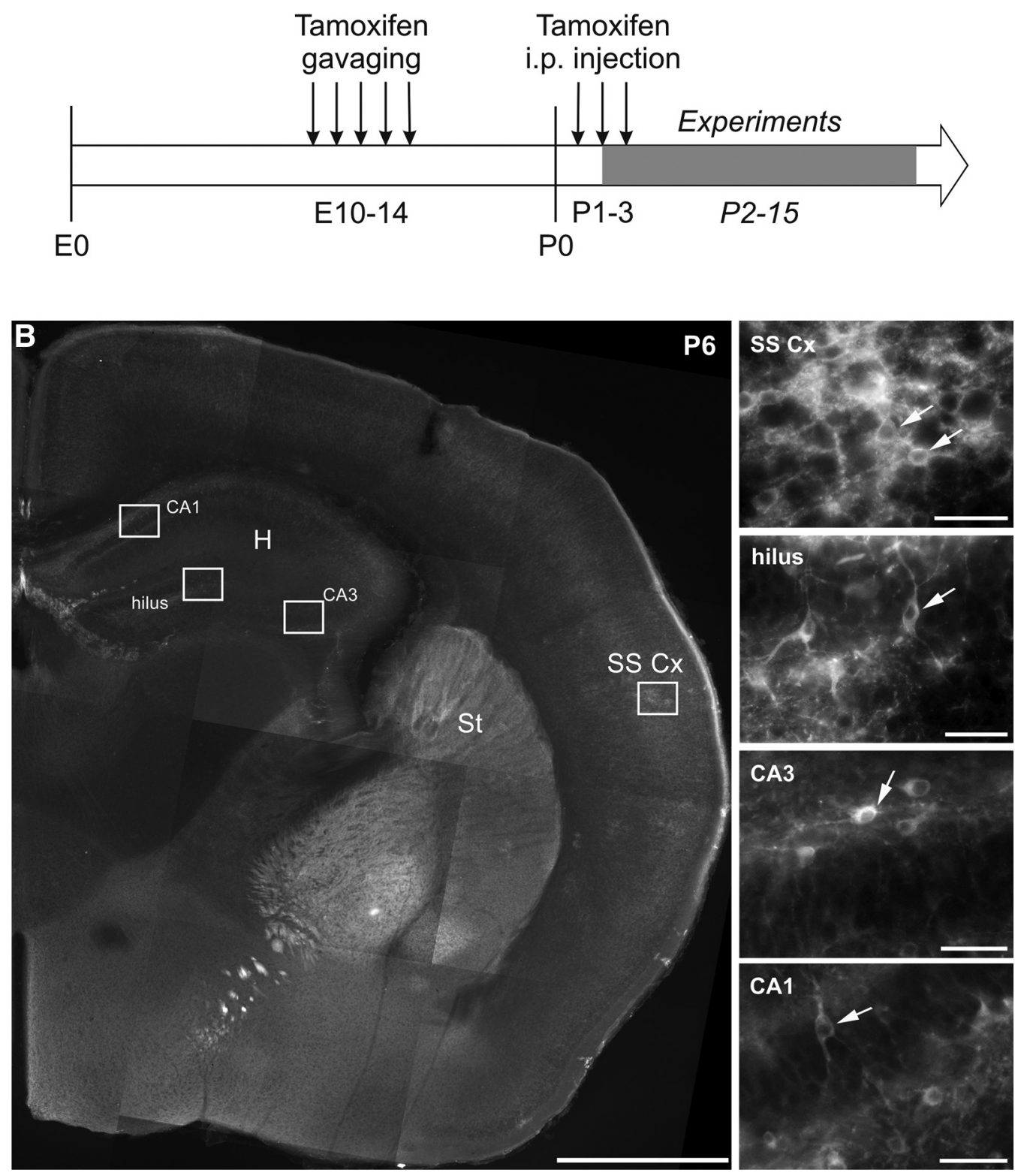

Figure 1. EGFP-ChR2 expression in interneurons of neonatal mice. A, Gad2::CreER-R26ChR2-EGFP mice were treated with tamoxifen during in utero development [embryonic days (E) 10 -E14] and the first days (P1-P3) after birth to induce EGFP-ChR2 expression in a Cre-dependent manner by P2-P15. B, Left, Distribution of EGFP-ChR2-expressing GAD neurons on coronal sections of the P6 mouse forebrain. SS C $x$, Somatosensory cortex; H, hippocampus; St, striatum. Scale bar, $1 \mathrm{~mm}$. Right, Enlargements of framed areas on the left panel (1-4 from the top). EGFP labeling (arrows) shows the soma and dendrites of numerous neurons in somatosensory cortex (1), hilus (2), stratum pyramidale of CA3 (3), and stratum oriens of CA1 (4) regions. Scale bars, $50 \mu \mathrm{m}$.

ment of GABA actions. However, exploring the actions of GABA is not a trivial technical task. It requires unperturbed intracellular ion homeostasis, resting membrane potential, and physiological stimulation of GABA receptors (Khazipov et al., 2015).

While traditional approaches to activate GABA receptors include application or photorelease of GABA agonists, or electrical stimulation of interneurons, recent advances in optogenetics provide an alternative method for selective and noninvasive stimulation of interneurons and thus physiological activation of GABA receptors. Using interneuron-specific promoters for conditional ChR2 expression, several mouse knock-in lines and vectors have been developed for selective photostimulation of interneurons. These models have been shown to be useful for various physiological applications for studying GABA actions at cellular and population levels, including mapping inhibitory cortical circuits (Kätzel et al., 2011; Luna and Morozov, 2012; Szydlowski et al., 2013), identifying inhibitory circuits between interneurons of different types (Moore and Wehr, 2013; Pfeffer et al., 2013; Quattrocolo and Maccaferri, 2013), identifying cellular compartments of the target neurons (Chiu et al., 2014), studying the role of interneurons in the generation of cortical rhythms (Stark et al., 2013; Schlingoff et al., 2014), signal processing (Atallah et al., 2012; Lee et al., 2012; Lovett-Barron et al., 2012; Owen et al., 2013; Sachidhanandam et al., 2013), and control of epileptic discharges (Ledri et al., 2014; Ladas et al., 2015). The optogenetic approach has also been used to characterize the hyperpolarizing actions of GABA in adult hippocampal slices using extracellular field potential recordings (Dine et al., 2014). Photo- 


\section{A neocortical interneuron in vitro}

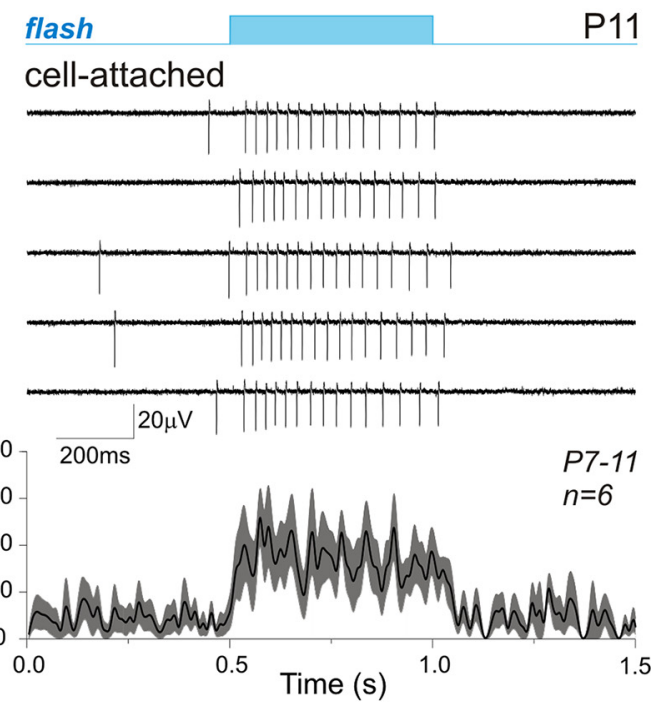

B flash P11
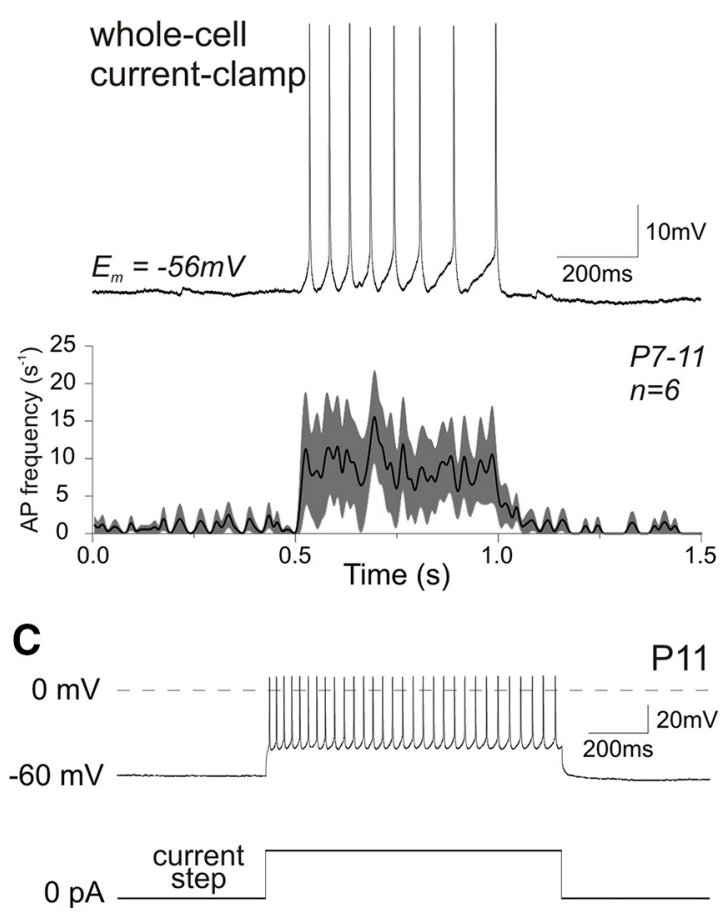

Figure 2. Photoactivation of EGFP-ChR2-expressing interneurons in mouse cortical slices. $A$, Example traces of cell-attached recording (at $-60 \mathrm{mV}$ ) of a P11 neocortical interneuron firing in response to the light pulse (blue bar above the traces) illuminating slice area around the tip of the patch pipette (as illustrated in Fig. 3A). $\boldsymbol{B}$, The current-clamp recording of an interneuron spiking during the light flash. $A, B$, Traces, AP frequency plot averaged over data obtained during cell-attached $(\boldsymbol{A}, n=6)$ and current-clamp $(\boldsymbol{B}, n=6)$ recordings from the given interneuron and hippocampal stratum oriens interneurons, individually illuminated by a $10-20$ $\mu \mathrm{m}$ light spot using a two-photon pulsed laser-scanning system coupled to a microscope. Data were fitted with basis spline function. The shaded region around the curve shows SE bands. $C$, Firing pattern of the same neuron as in $\boldsymbol{A}$ and $\boldsymbol{B}$ during a depolarizing current step.

stimulation of ChR2-expressing interneurons has also been shown to produce inhibitory actions on target muscles in the early developmental stages of Caenorhabditis elegans (Han et al., 2015). In mice expressing ChR2 in the cerebellar molecular layer, interneurons under the control of the neuronal nitric oxide syn- thase promoter, excitatory GABA actions on parallel fibers have been demonstrated in adults in vivo (Astorga et al., 2015). So far, optogenetic approaches selectively targeting GABAergic neurons have not been used in rodents at early developmental stages.

In the present study, we have used photostimulation of GABAergic neurons expressing ChR2 in a mouse line reported previously (Kätzel et al., 2011) to indirectly assess the excitatory/ inhibitory actions of GABA on glutamatergic cells in the developing neocortex and hippocampus. Readout of the effects of GABA on principal neurons consisted of measuring a change in the frequency of EPSCs in response to photostimulation of GABAergic neurons. We show that mice with ChR2 expression in GABAergic neurons (1) enable selective and noninvasive photostimulation of interneurons during the early postnatal period and (2) display a developmental excitatory-to-inhibitory switch in GABA action in cortical slices in vitro, but also (3) reveal inhibitory GABA actions on spontaneous EPSC frequency in the immature hippocampus and neocortex in vivo. Thus, this approach can be useful for investigations of excitatory/inhibitory GABA actions during development as well as in other physiological and pathological conditions where an assessment of GABA actions is required.

\section{Materials and Methods}

This work has been performed in accordance with the EU Directive 2010/63/EU for animal experiments, and all animal-use protocols were approved by the French National Institute of Health and Medical Research (Protocol N007.08.01).

Mice expressing ChR2-EGFP in GAD2-positive interneurons. Experiments were performed using mice pups of both sexes obtained from crossing female Swiss mice (C.E. Janvier, France) with doublehomozygous males of the Gad2::CreER-R26ChR2-EGFP mouse line described previously (Kätzel et al., 2011). To induce CreER activity, we administered a tamoxifen solution by gavaging (force-feeding) pregnant mice using silicon-protected needles (Fine Science Tools), and subsequent intraperitoneal injection in neonatal pups as illustrated in Figure $1 A$. Pregnant mice were force-fed at $10-14 \mathrm{~d}$ of gestation $(26 \mathrm{~mm}$ solution, $6.6 \mathrm{ml} / \mathrm{kg})$, and the pups were injected with tamoxifen $(13 \mathrm{~mm}$ solution, $2.14 \mathrm{ml} / \mathrm{kg}$ ) on $\mathrm{P} 1-\mathrm{P} 3$ to promote early expression of ChR2EGFP (Fig. 1B). Experiments were performed $\geq 24 \mathrm{~h}$ after the first postnatal tamoxifen injection. The number of postnatal tamoxifen injections strongly determined the probability of recording neurons responsive to photostimulation. The best success rate $(75-100 \%$ of recorded neurons responding to light flashes) was observed in pups treated with four tamoxifen injections after birth.

Brain slice preparation. Acute brain slices containing the hippocampus and neocortex were obtained from P2-P15 Gad2::Cre ER-R26ChR2-EGFP or wild-type mice of both sexes. Mice pups were cryoanaesthetized (P2-P5) or anesthetized with chloral hydrate ( $>$ P5) $350 \mathrm{mg} / \mathrm{kg}$, intraperitoneally. The brain was rapidly removed from decapitated animals to ice-cold $\left(2-5^{\circ} \mathrm{C}\right)$ choline-based (unless indicated) cutting solution containing the following (in $\mathrm{mm}$ ): 110 choline chloride, $2.5 \mathrm{KCl}, 25 \mathrm{NaHCO}_{3}, 7$ glucose, $7 \mathrm{MgCl}_{2}, 1.25 \mathrm{NaH}_{2} \mathrm{PO}_{4}, 0.5 \mathrm{CaCl}_{2}$. Brain hemispheres were separated and, after removing the cerebellum, $400-\mu \mathrm{m}$-thick transverse slices were cut from one of the hemispheres using a Vibratome (VT 1000E, Leica). From 1 to $8 \mathrm{~h}$ before recording, slices were kept at room temperature $\left(20-22^{\circ} \mathrm{C}\right)$ in oxygenated artificial CSF (ACSF) of the following composition (in $\mathrm{mm}$ ): $126 \mathrm{NaCl}, 3.5 \mathrm{KCl}, 2$ $\mathrm{CaCl}_{2}, 1.3 \mathrm{MgCl}_{2}, 25 \mathrm{NaHCO}_{3}, 1.2 \mathrm{NaH}_{2} \mathrm{PO}_{4}$, and 11 glucose, $\mathrm{pH}$ 7.4. For recording, slices were placed into a submerged chamber on a nylon net and superfused on both sides with ACSF at $32^{\circ} \mathrm{C}$ (unless indicated) and at a flow rate of $2-4 \mathrm{ml} / \mathrm{min}$. In some experiments, slices were superfused with modified ACSF ( $\mathrm{mACSF}$ ) of the following composition (in mM): $126 \mathrm{NaCl}, 3.0 \mathrm{KCl}, 1.5 \mathrm{CaCl}_{2}, 1.0 \mathrm{MgCl}_{2}, 25 \mathrm{NaHCO}_{3}, 1.2$ $\mathrm{NaH}_{2} \mathrm{PO}_{4}$, and 11 glucose, $\mathrm{pH}$ 7.4.

Surgery. All surgical procedures were performed under deep isoflurane anesthesia ( $3 \%$ for induction and $1-1.5 \%$ for maintenance at $0.8 \mathrm{~L} / \mathrm{min}$ ). 
A

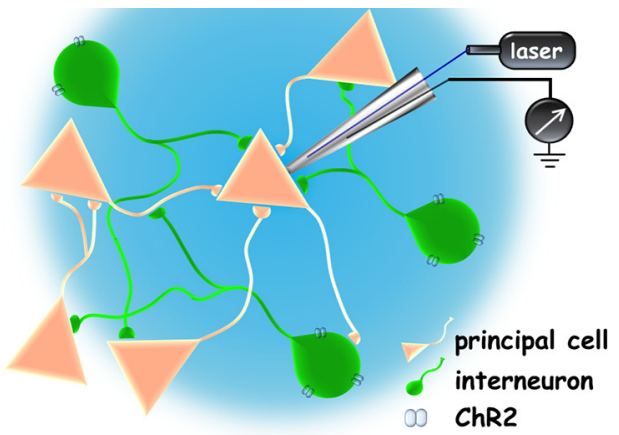

C

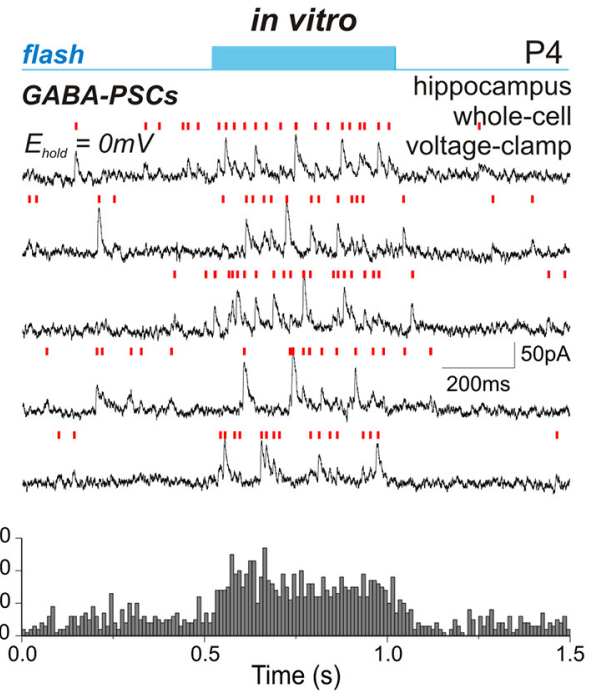

E

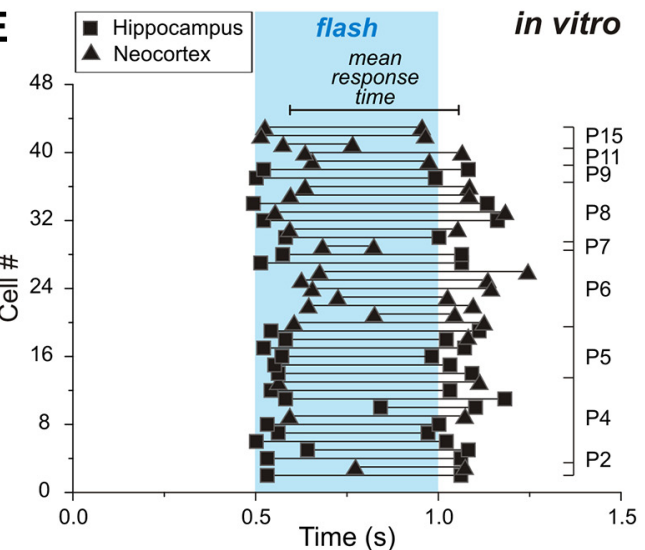

G

in vitro $\square$ Hippocampus

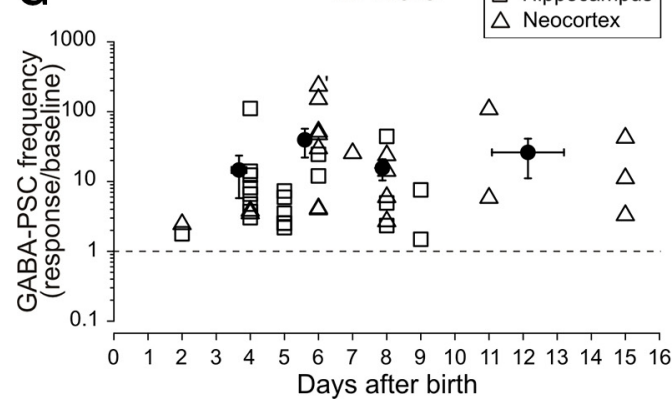

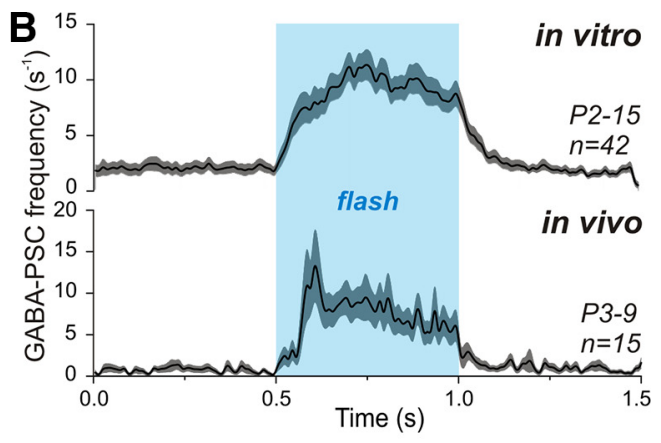

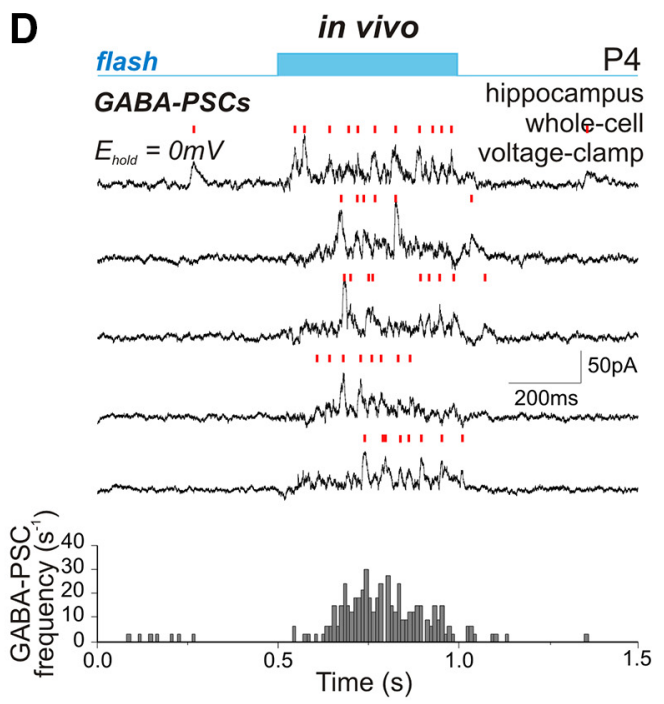

$\mathbf{F}$
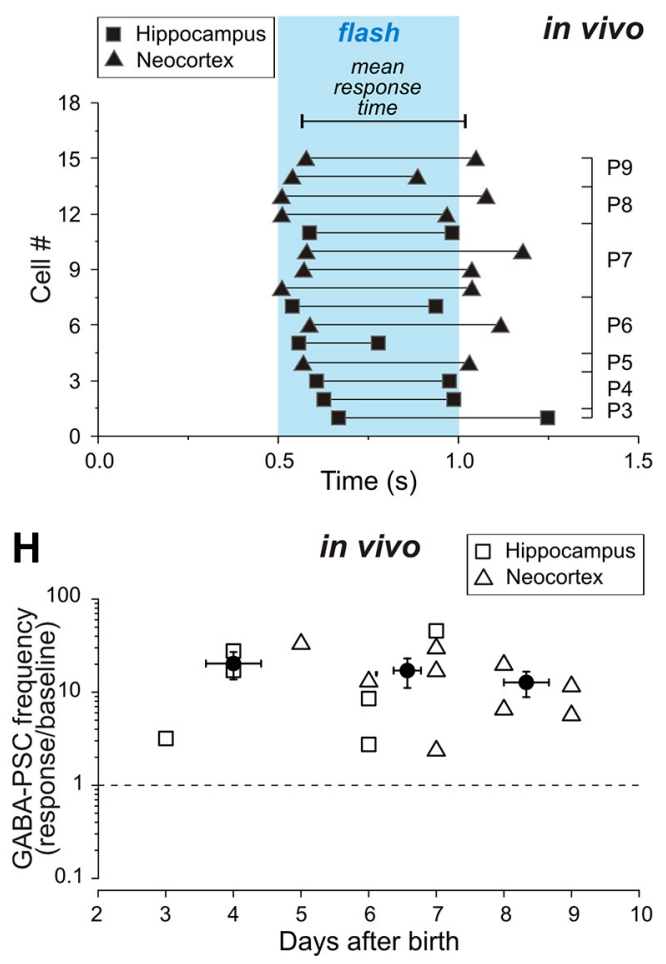

Figure 3. $G A B A(A)$-mediated postsynaptic response to photoactivation of local interneurons in the neonatal mouse cortex in vitro and in vivo. $A$, Schematic drawing of the experimental setup demonstrates patch-clamp recording from the principal neuron during light stimulation of EGFP-ChR2-expressing interneurons located close to the light source. $\boldsymbol{B}$, Averaged plot of GABA-PSC frequency change in response to local interneurons photoactivation by the light pulse (highlighted area) in P2-P15 mouse cortical slices (on the top, $n=42$ ) and in the P3-P9 mouse cortex in vivo (on the bottom, $n=13$ ) fitted with basis spline function. The shaded region around the curve shows SE bands. C, D, The whole-cell voltage-clamp recording of GABA-PSCs with a low-chloride pipette solution at the reversal potential of Glu-EPSCs in a hippocampal slice $(\boldsymbol{C})$ and the intact brain $(\boldsymbol{D})$ of P4 mice. Five responses evoked by the light flash are shown with (Figure legend continues.) 
The skin and a periosteum were removed from the skull surface. After drying out, the skull surface was covered with dental cement (Grip Cement, Caulk Dentsply) except for a $\sim 0.5 \mathrm{~mm}^{2}$ area on the left parietal bone above the primary somatosensory or posterior parietal cortex. For recording, the pups were surrounded by a cotton nest and heated via a thermal pad coupled to an automatic temperature controller (TC-344B, Warner Instruments; $35-37^{\circ} \mathrm{C}$ ) and each animal's head was attached to a metal stage with a round opening in the center using the dental cement. A silver wire (200 $\mu \mathrm{m}$ diameter) placed caudally in the parietal cortex was used as the reference electrode. To position the recording patch pipette, a hole was drilled in the parietal bone part free of dental cement, and the exposed dura mater was subsequently dissected using a 27 ga needle. At the end of surgery, urethane $(0.5-1 \mathrm{~g} / \mathrm{kg})$ was intraperitoneally administered to the mice pups. In one P5 animal, recordings were performed under ketamine $(80 \mathrm{mg} / \mathrm{kg})$-xylazine $(10 \mathrm{mg} / \mathrm{kg})$ anesthesia.

Electrophysiology. In vitro and in vivo patch-clamp recordings were performed using an Axopatch 200B (Molecular Devices). Patch electrodes were made from borosilicate glass capillaries (GC150F-15, Harvard Apparatus). The patch electrodes had a resistance of 6-8 $\mathrm{M} \Omega$ when filled with the pipette solution containing the following (in $\mathrm{mM}$ ): 135 K-methanesulfonate, $4 \mathrm{Na}_{2} \mathrm{ATP}, 0.3 \mathrm{Na}_{2} \mathrm{GTP}, 2 \mathrm{MgCl}_{2}, 10 \mathrm{HEPES} 10, \mathrm{pH}$ 7.3. Patch-clamp recordings in vivo were performed blindly, and the positions of recorded neurons were identified during post hoc reconstruction of the DiI trace of the recording pipette on $100-\mu \mathrm{m}$-thick coronal brain sections. During recordings from brain slices in vitro, patchclamp recordings were performed $100-200 \mu \mathrm{m}$ below the slice surface to avoid sampling of neurons within the damaged zone (Dzhala et al., 2012). The signals were digitized at $10 \mathrm{kHz}$ using a Digidata 1440 analogto-digital converter (Molecular Devices).

To monitor the excitatory/inhibitory effects of GABA under various experimental conditions in wild-type mice in vitro, we examined the responses evoked by local puff application of GABA in visually identified L5/6 neocortical cells recorded in loose cell-attached mode with ACSF in the pipette solution. The PV830 Pneumatic PicoPump (WPI) was used to puff-apply GABA (200 $\mu \mathrm{m}$ in ACSF) from a glass pipette positioned at a distance of $<100 \mu \mathrm{m}$ from the soma of the recorded cell. The application pressure varied from 10 to $20 \mathrm{psi}$, and the duration of the puff was $10 \mathrm{~ms}$.

Photostimulation. The photostimulation during blind patch-clamp recordings was accomplished using a continuously radiating $473 \mathrm{~nm}$ DPSS blue laser system (DragonLasers) with analog modulation of output power (1-100 mW) using an "optopatcher" system as described in previous studies (Katz et al., 2013; Minlebaev et al., 2013). The coherent light passed through the collimating lens and was guided by a multimode $50 \mu \mathrm{m}$ optical fiber to reach a patch-pipette holder. A hole $(\sim 0.3 \mathrm{~mm}$ in diameter $)$ was drilled in the patch holder to fit the optical fiber. Thereafter the hole was filled with dental cement to secure the fiber and to prevent the leakage of air pressure from the holder. The optical fiber length inside the patch pipette exceeded the length of the signal wire by $2-5 \mathrm{~mm}$, so that the fiber tip appeared in the pipette's neck. As reported previously (Katz et al., 2013), with this illumination procedure in brain tissue, the light

$\leftarrow$

(Figure legend continued.) a blue bar above the traces indicating the onset and the length of the light pulse. Red bars indicate individual GABA-PSCs. Below, Corresponding GABA-PSC frequency histograms based on the results of $30-100$ photostimulation trials (bin size, $10 \mathrm{~ms}$ ). $\boldsymbol{E}$, $\boldsymbol{F}$, The time course of light-evoked GABA-mediated responses at different postnatal ages in vitro $(\boldsymbol{E})$ and in vivo $(\boldsymbol{F})$. Each pair of symbols shows the onset and the end of GABA response to the light flash (highlighted area) recorded from individual hippocampal (squares) or neocortical (triangles) neurons. Animal age is indicated on the right. $\mathbf{G}, \boldsymbol{H}$, Pooled data on GABA-PSC frequency during light-evoked responses normalized to the baseline frequency in hippocampal (squares) and neocortical (triangles) neurons at different postnatal ages in vitro (G) and in vivo $(\boldsymbol{H})$. Closed circles show mean values with SE. Baseline GABA-PSC frequency was calculated in the $0.5 \mathrm{~s}$ preceding the light pulse. In case of the absence of GABA-PSCs detected during this time window, the number of GABA-PSCs for baseline frequency calculation was considered by convention to be equal to 1 (marked with a stroke near the symbol). GABA-PSC frequency during the response was calculated within an individual time window for each neuron (displayed in $\boldsymbol{E}$ and $\boldsymbol{F}$ ). intensity is attenuated by $\sim 70 \%$ at a distance of $1 \mathrm{~mm}$ compared with the intensity measured at the tip of the pipette.

Photostimulation of individual interneurons was performed using a $488 \mathrm{~nm}$ continuous-wave laser (Sapphire $488 \mathrm{LP}$, Coherent) coupled to an xy-scanning system of a two-photon microscope (TriM Scope II, LaVision BioTec) as described previously (Marissal et al., 2012).

Histology. Gad2::CreER-R26ChR2-EGFP mice pups (P6) were anesthetized with isoflurane and perfused through the heart with $5 \mathrm{ml}$ of fixative containing $4 \%$ paraformaldehyde in PBS. Brains were extracted and postfixed overnight in fixative. After several washings in PBS, brains were cut into $100-\mu \mathrm{m}$-thick coronal sections. The sections were then treated for immunocytochemical detection of GFP. Briefly, after preincubation in 5\% normal donkey serum, sections were incubated in a rabbit antibody directed against GFP (1:10,000; A6455, Invitrogen), then incubated in a secondary antibody conjugated with Al488 (1:500; Invitrogen). Images were obtained with a Zeiss AxioImager Z2 microscope coupled to a camera (Zeiss AxioCam MR3). Immunofluorescence images were acquired using a halogen HBO lamp associated with a 470/40 $\mathrm{nm}$ filter cube for detection of Al488.

Reagents. The stock solutions of (-)-bicuculline methiodide (10 mM), bumetanide $(10 \mathrm{~mm})$ and GABA $(20 \mathrm{~mm})$ were stored in the freezer before use as aliquots in tightly sealed vials. All reagents were purchased from Sigma-Aldrich and Tocris Bioscience.

Data analysis. pCLAMP 10.1 (Molecular Devices), Mini Analysis 6.0.7 (Synaptosoft), Origin 7.0 (Microcal Software), and custom-written functions in Matlab (MathWorks) were used for data acquisition and analysis. The response time window was calculated individually for each recorded neuron. The onset and the end of responses were determined as time points corresponding to the maximum and minimum of the curve obtained after subtraction of the cumulative peristimulus time histogram from the diagonal reflecting constant event frequency (Mitrukhina et al., 2015). Nonoverlapping unitary glutamatergic EPSCs (Glu-EPSCs) were manually selected for the EPSCs' amplitude measurements. The statistical significance of differences between groups of data was assessed using the Wilcoxon signed-rank test and Mann-Whitney test. Group measures are expressed as means \pm SE. Error bars also indicate SE. The level of significance was set at $p<0.05$.

\section{Results}

Patch-clamp recordings were performed from the neocortex and hippocampus of P2-P15 mice expressing ChR2 in GAD2positive interneurons (Kätzel et al., 2011) in vitro and in vivo to characterize the developmental profile of photostimulationevoked GABAergic responses and actions of GABA on postsynaptic neurons.

\section{Photoactivation of GABAergic neurons}

We first characterized the ability of single interneurons to respond upon photostimulation by laser light during the postnatal period. The interneurons were recorded in neocortical and hippocampal slices at P6-P11 and individually stimulated by focused light (10-20 $\mu \mathrm{m}$ light spot size, $500 \mathrm{~ms}$ flash duration) using a $488 \mathrm{~nm}$ laser-scanning system coupled to a microscope or by wide-field illumination with an intrapipette light source. In cell-attached recordings, interneurons responded to each light pulse (delivered every $15 \mathrm{~s}$ ) with on average a fourfold increase in action potential (AP) firing rate (from $4.4 \pm 0.7 \mathrm{~s}^{-1}$ to $16.3 \pm 3.1$ $\mathrm{s}^{-1} ; n=6$ cells; P7-P11; $p=0.03$; paired-sample Wilcoxon signed-rank test; Fig. 2A). Increased AP firing in response to photostimulation was also observed in interneurons during whole-cell current-clamp recordings, where AP frequency increased from the baseline level of $0.9 \pm 0.5 \mathrm{~s}^{-1}$ to $8.9 \pm 4.5 \mathrm{~s}^{-1}$ under illumination ( $n=6$ cells; $\mathrm{P} 7-\mathrm{P} 11 ; p=0.03$; paired-sample Wilcoxon signed-rank test; Fig. $2 B$ ). During voltage-clamp recordings at holding potentials close to resting membrane potential values $(-60 /-70 \mathrm{mV})$ the light pulse drove interneurons to 
A

\section{in vitro}

flash GABA-PSCs
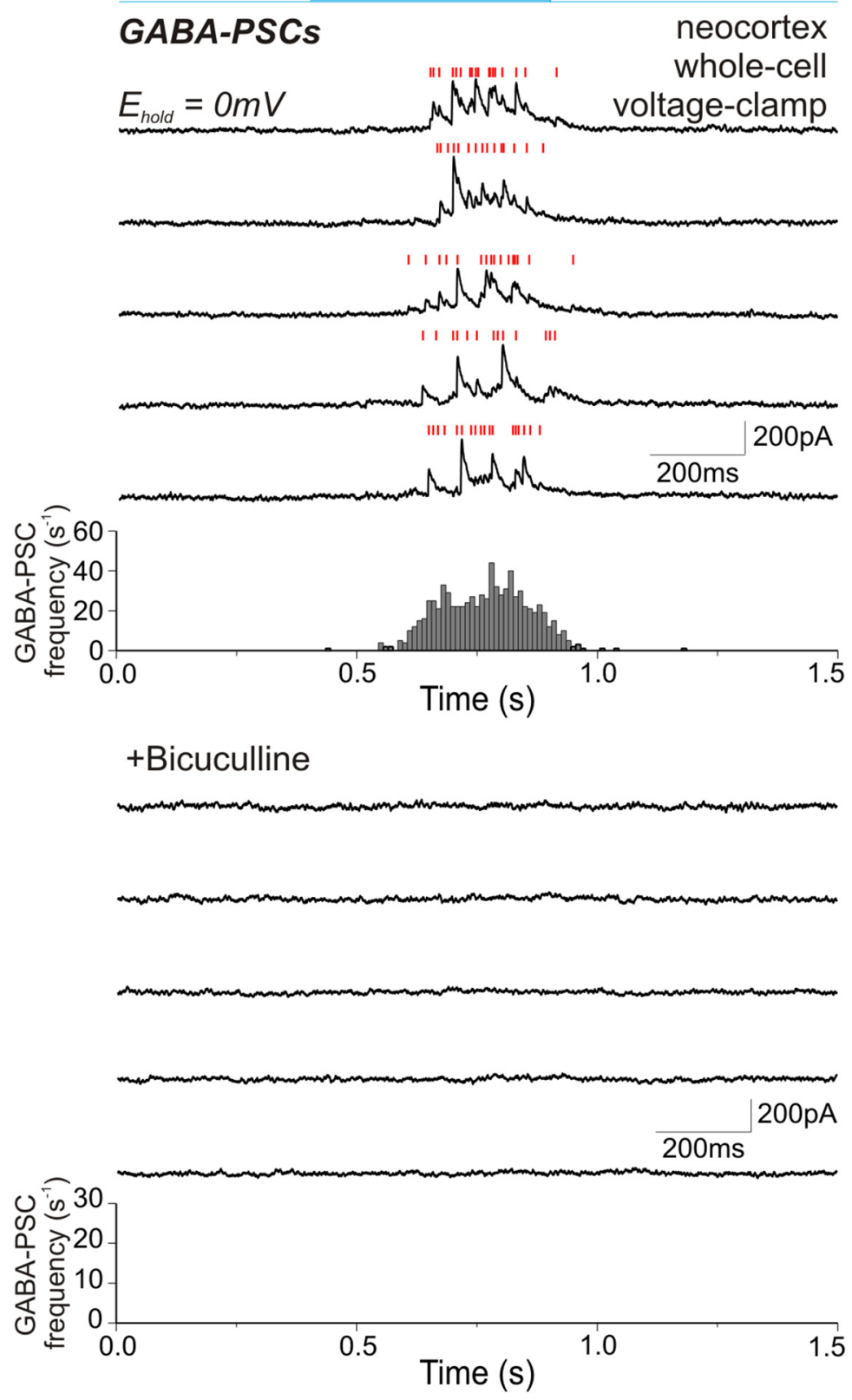

B

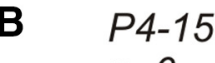

$n=6$

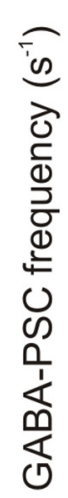

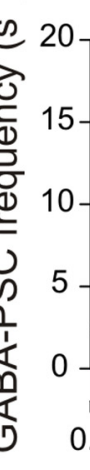$$
\text { ก }
$$

\section{in vitro}

flash

P6

neocortex whole-cell
Itage-clamp

\section{.}

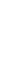


A
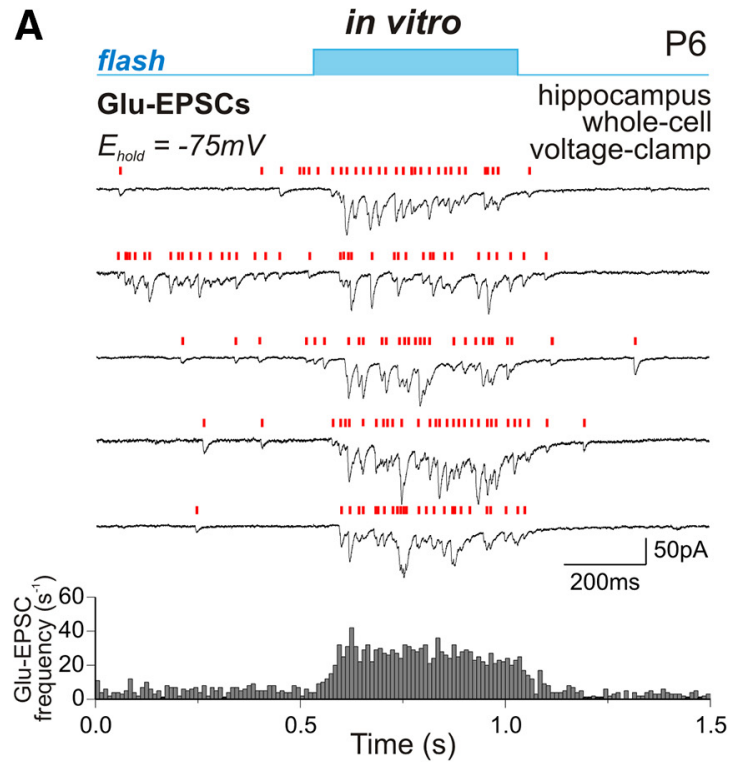

C

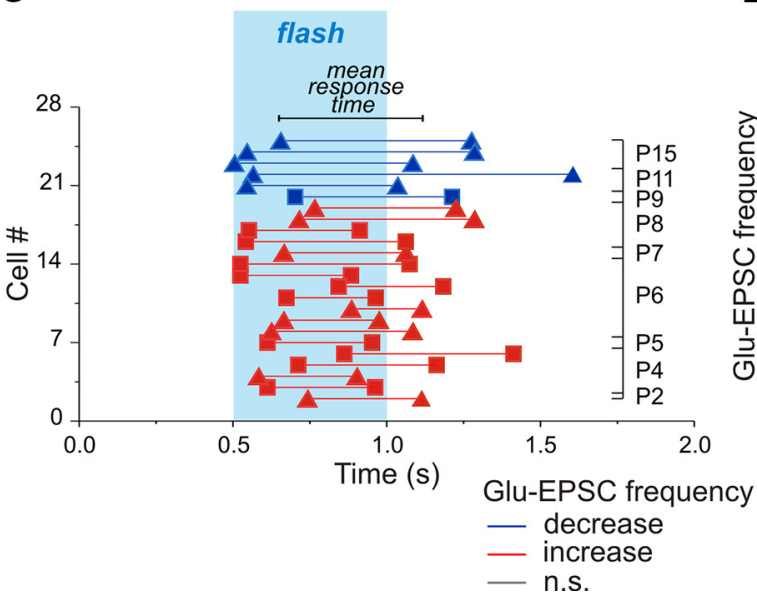

B
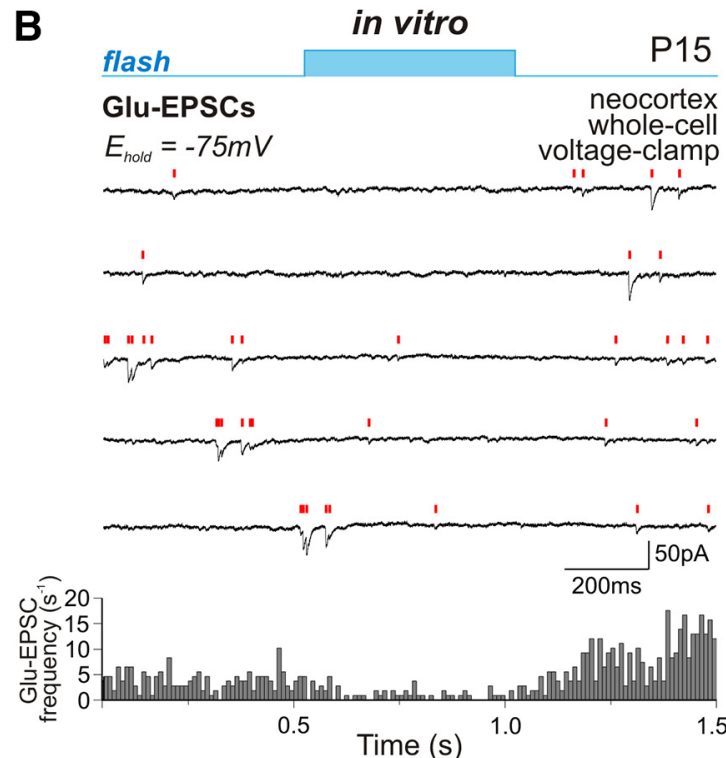

D

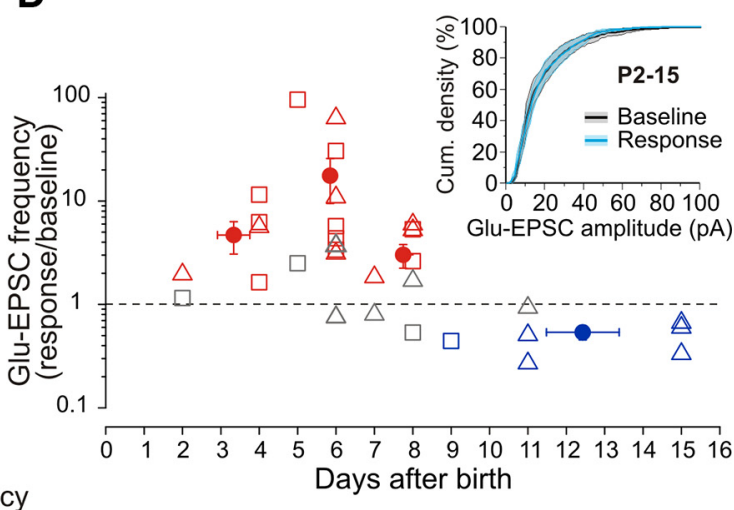

$\square$ Hippocampus

$\triangle$ Neocortex

Figure 5. Photoactivation of interneurons induces glutamate release from principal cells in neonatal but not in adolescent mice in vitro. $A, B$, Example traces of Glu-EPSCs recorded during photostimulation at the reversal potential of GABA-PSCs $(-75 \mathrm{mV})$ in P6 hippocampal $(\boldsymbol{A})$ and P15 neocortical $(\boldsymbol{B})$ slices. Red bars indicate individual Glu-EPSCs. Below, Corresponding histograms of Glu-EPSC frequency based on results of 100-110 photostimulation trials. C, The time course of glutamatergic response evoked by the light pulse (highlighted area) at different postnatal ages (blue and red symbols correspond to a decrease and an increase in Glu-EPSC frequency during responses, respectively). Each pair of symbols shows the onset and the end of response recorded from individual hippocampal (squares) or neocortical (triangles) neurons. Animal age is indicated on the right. D. Pooled data on the change in Glu-EPSC frequency during the light pulse in relation to the baseline frequency in hippocampal (squares) and neocortical (triangles) neurons of P2-P15 mice. Color code of symbols is same as in C. The Glu-EPSC frequency during response was calculated within a time window unique to each neuron (displayed in C). Gray symbols correspond to the neurons where no significant change in Glu-EPSC frequency was detected during illumination. Response frequency in these neurons was calculated within the mean-response time window. Closed circles show mean values with SE. Note that photostimulation of interneurons elicits an increase in Glu-EPSC frequency during the first postnatal week and a decrease in Glu-EPSC frequency after P8, indicating a developmental excitatory-to-inhibitory switch in the action of GABA photoreleased from interneurons on glutamatergic neurons. The cumulative distribution of Glu-EPSC amplitudes during baseline activity (black trace) and throughout the photostimulation-evoked response (blue trace) is shown in the inset graph. The shaded area around the curves corresponds to SE bands.

$0.8 \pm 0.2 \mathrm{~s}^{-1}(n=6$ hippocampal and 9 neocortical cells; P3-P9; $p=6.1 \cdot 10^{-5}$; paired-sample Wilcoxon signed-rank test; Fig. $3 D, H)$. The photostimulation-evoked response had its average onset at $65 \pm 12 \mathrm{~ms}$ after the flash start and lasted for $451 \pm 27$ $\mathrm{ms}$, thereby exhibiting a time course very similar to the lightevoked GABA-mediated responses observed in slices $(n=15$; Fig. $3 B, F)$.

Together, these results indicate that starting from P2 onwards, functional ChR2 is already expressed in cortical interneurons of Gad2::CreER-R26ChR2-EGFP mice, and that photostimulation enables selective activation of GABAergic neurons both in slices and in the intact cortex in vivo.

\section{Glutamatergic responses on photostimulation of} GABAergic neurons

Using the same approach, we assessed the excitatory/inhibitory actions of GABA on glutamatergic neurons. We assumed that wide-field photostimulation of GABA release on glutamatergic neurons should change their firing, resulting in an increase or a decrease in EPSC frequency, depending on whether presynaptic glutamatergic neurons targeting the recorded cell are excited or inhibited by GABA, respectively.

With this aim, whole-cell recordings of Glu-EPSCs were performed at the reversal potential of GABA-PSCs $(-75 \mathrm{mV})$. In neocortical and hippocampal slices prepared from P2-P8 mice, 
A

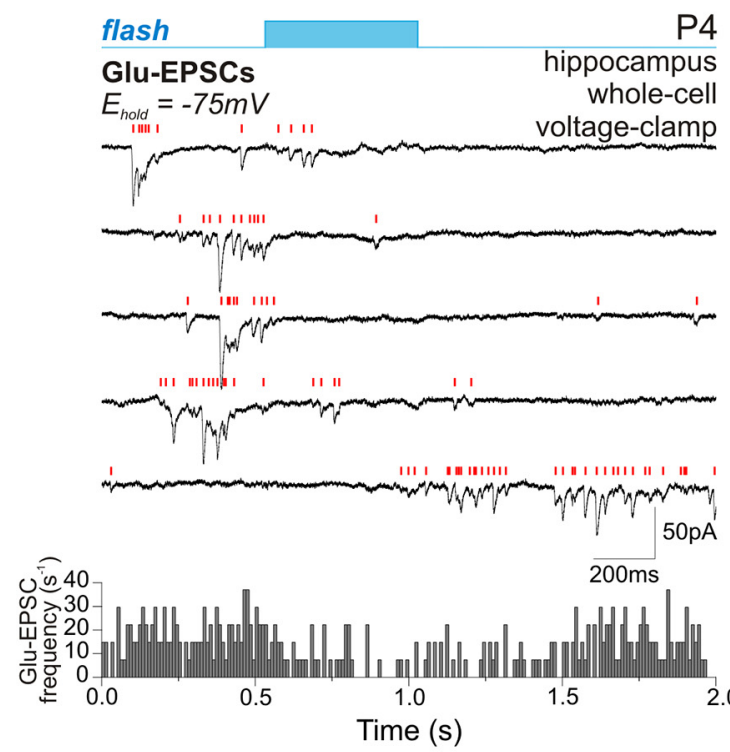

C

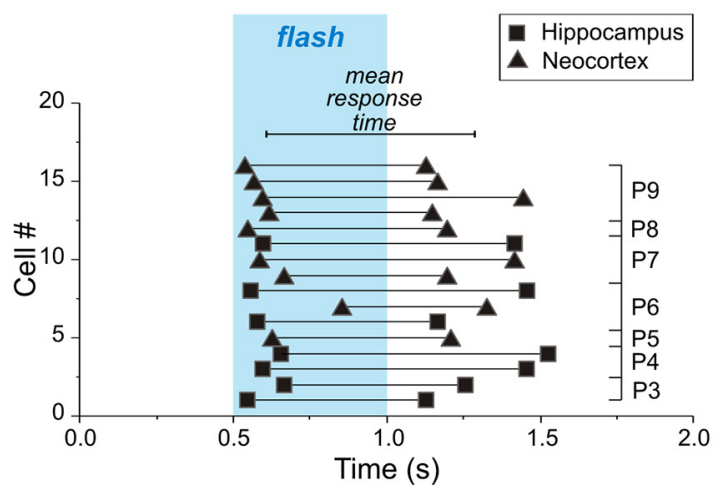

B

\section{in vivo}
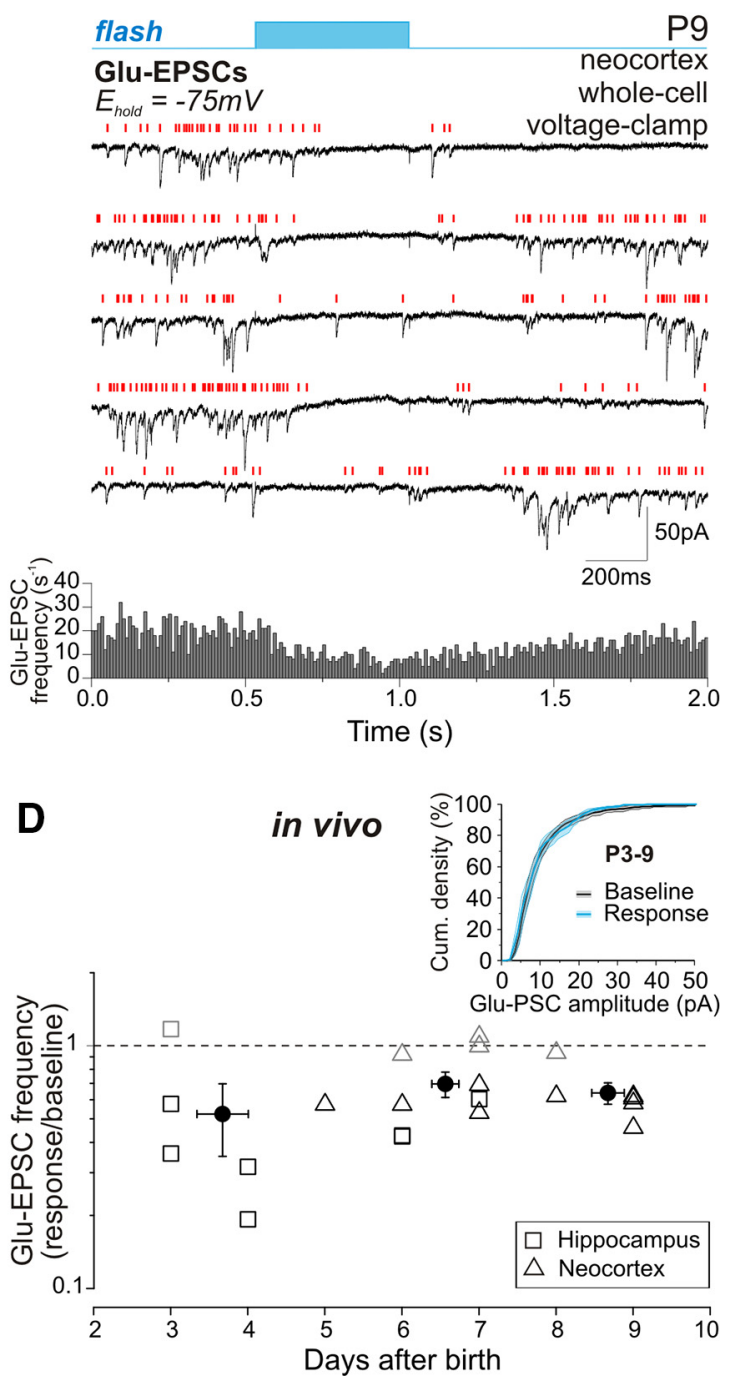

Figure 6. Photoactivation of interneurons suppresses glutamate release from principal cells in neonatal and adolescent mice in vivo. $\boldsymbol{A}, \boldsymbol{B}$, Example traces of Glu-EPSCS recorded during photostimulation at the reversal potential of GABA-PSCS $(-75 \mathrm{mV})$ in P4 hippocampal $(\boldsymbol{A})$ and P15 neocortical $(\boldsymbol{B})$ neurons in vivo. Red bars indicate individual Glu-EPSCs. Below, Corresponding histograms of Glu-EPSC frequency based on $100-230$ stimulation sweeps. C, The time course of glutamatergic responses evoked by the light pulse (highlighted area) at different postnatal ages. Each pair of symbols shows the onset and the end of response recorded from individual hippocampal (squares) or neocortical (triangles) neurons. The animal age is indicated on the right. $D$, Pooled data on the change in Glu-EPSC frequency during the light pulse in relation to the baseline frequency in hippocampal (squares) and neocortical (triangles) neurons of P3-P9 mice. Glu-EPSC frequency during the response was calculated within an individual time window for each neuron (displayed in C). Gray symbols correspond to the neurons where no significant change in Glu-EPSC frequency was detected during illumination. The response frequency in these neurons was calculated within the mean-response time window. Closed circles show mean values with SE. The cumulative distribution of Glu-EPSC amplitudes during baseline activity (black trace) and throughout the photostimulation-evoked response (blue trace) is shown in the inset graph. The shaded area around the curves corresponds to SE bands.

photoactivation of GABAergic neurons caused an increase in EPSC frequency from $1.3 \pm 0.3 \mathrm{~s}^{-1}$ to $6.4 \pm 1.6 \mathrm{~s}^{-1}$ (by $392 \%$ from control values; $n=25$ cells, $p=5.2 \cdot 10^{-6}$; paired-sample Wilcoxon signed-rank test; Fig. $5 A, D)$. In contrast, at P9-P15, the light pulses caused a reduction in EPSC frequency from $6.5 \pm$ $3.0 \mathrm{~s}^{-1}$ to $4.7 \pm 2.8 \mathrm{~s}^{-1}$ (by $28 \% ; n=7$ cells; $p=0.016$; pairedsample Wilcoxon signed-rank test; Fig. $5 B, D$ ). Age-dependent changes in EPSC frequency response were not associated with any significant change in EPSC amplitude ( $19 \pm 3$ pA during baseline activity and $18 \pm 2$ pA during response; $n=9$ cells; P2-P15; $p=$ 0.91; paired-sample Wilcoxon signed-rank test; Fig. $5 D$ ). Glutamatergic responses lasted on average $468 \pm 35 \mathrm{~ms}$ and were $54 \mathrm{~ms}$ delayed compared with GABA-mediated responses, occurring with a mean onset time of $148 \pm 23 \mathrm{~ms}$ after the flash start $(n=24$ cells; P2-P15; $p=0.02$; Mann-Whitney test; Fig. $5 C$ ).
We used a similar approach to assess the effects of GABA on the frequency of spontaneous EPSCs in Gad2::CreERR26ChR2-EGFP mice in vivo. Whole-cell recordings were performed in head-restrained animals under urethane $(0.5-1 \mathrm{~g} / \mathrm{kg})$ or ketamine $(80 \mathrm{mg} / \mathrm{kg})$-xylazine $(10 \mathrm{mg} / \mathrm{kg})$ anesthesia with optopatch illumination. In contrast to the developmental switch described above, the effect of photostimulation of GABAergic neurons on spontaneous EPSC frequency in vitro, we found that photostimulation of GABAergic neurons in vivo caused a uniform, age-independent decrease in EPSC frequency in hippocampal and neocortical neurons of $\mathrm{P} 3-\mathrm{P} 9$ animals from $6.0 \pm$ $1.3 \mathrm{~s}^{-1}$ to $3.8 \pm 0.8 \mathrm{~s}^{-1}$ (i.e., by $37 \% ; n=21$ cells; $p=1.3 \cdot 10^{-5}$; paired-sample Wilcoxon signed-rank test; Fig. $6 A, B, D$ ). This decrease in EPSC frequency was also significant in subgroups of animals aged P3-P5, P6-P7, and P8-P9 (Fig. 6D), as well as in 

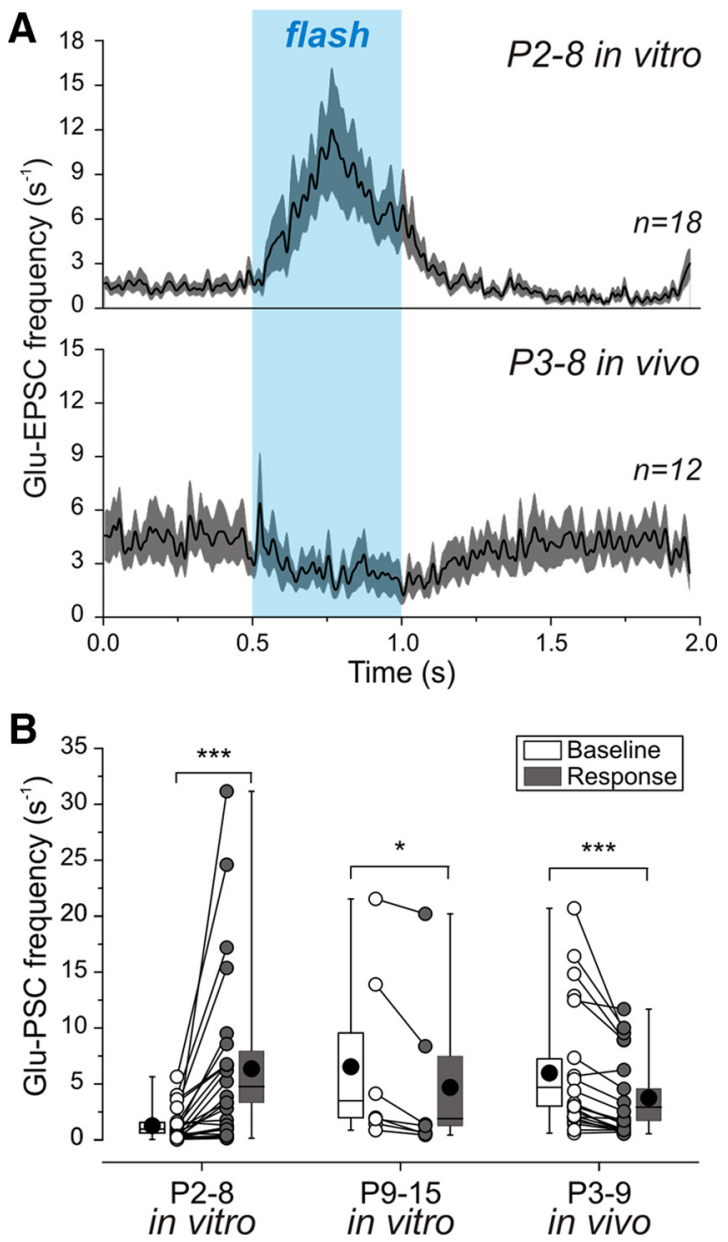

Figure 7. Characteristics of the glutamatergic response evoked by photostimulation in cortical neurons of Gad2::CreER-R26ChR2-EGFP neonatal mice in vitro and in vivo. $\boldsymbol{A}$, The time course of the Glu-EPSC frequency change in response to photoactivation of local interneurons by the light flash (highlighted in blue) recorded during the first postnatal week from cortical slices (P2-P8, $n=18$ cells, upper plot) and the intact cortex in vivo (P3-P8, $n=12$ cells, lower plot). Data were averaged for the neurons where photostimulation evoked a significant change in Glu-EPSC frequency (displayed in Figs. 5C, 6C; neurons shown by gray symbols in Figs. 5D and 6D are not included) and fitted with basis spline function. The shaded area around the curve indicates SE bands. $\boldsymbol{B}$, Statistical plot of Glu-EPSC frequency observed during baseline activity and throughout the light-evoked response in different age groups in vitro and in vivo. Each pair of connected circles corresponds to an individual neuron. The medians of boxplots are shown by black lines; mean values are shown by black circles. Glu-EPSC frequency data in $B$ include all cells recorded in vitro ( $n=25$ cells at P2-P8; $n=7$ cells at P9-P15) and in vivo ( $n=21$ cells) and displayed in Figures $5 D$ and $6 D$, respectively. ${ }^{*} p<0.05{ }^{* * *} p<0.001$.

one cortical neuron of a P5 mouse recorded under ketaminexylazine anesthesia where baseline frequency of $3.0 \mathrm{~s}^{-1}$ dropped to $1.7 \mathrm{~s}^{-1}$ in response to illumination. The amplitude of EPSCs remained unchanged during the response to photostimulation $(10 \pm 1 \mathrm{pA}$ during baseline activity and $10 \pm 1 \mathrm{pA}$ during response; $n=6$ cells; P3-P9; $p=0.44$; paired-sample Wilcoxon signed-rank test; Fig. 6D). The decrease in EPSC frequency started on average at $110 \pm 19 \mathrm{~ms}$ after the flash onset and lasted for $678 \pm 37 \mathrm{~ms}(n=16$ cells; P3-P9; Fig. $6 C)$. Light-activated glutamatergic response onset in vivo, thereby, was $45 \mathrm{~ms}$ delayed compared with GABA-mediated responses ( $p=0.03$; Man$\mathrm{n}$-Whitney test). The time course of the photostimulationevoked change in EPSC frequency matched that observed in cortical slices in vitro (Fig. $7 A$ ).

\section{Dependence of excitatory action of GABA in neonatal slices on urethane and other experimental conditions}

The difference in the network effects of GABA in the immature neurons, excitatory in vitro and inhibitory in vivo, may result from a difference in the experimental conditions provided in vitro and in vivo. Therefore, we explored the effects of various experimental conditions that could account for the difference in GABA actions, including the effects of urethane, ACSF electrolyte constitution, slicing medium, and temperature. With this aim, we monitored the effects of locally puff-applied GABA $(200 \mu \mathrm{M}, 10$ ms, $10-20 \mathrm{psi}, 10 \mathrm{~s}$ intervals) on firing of neocortical neurons recorded in loose cell-attached mode in slices prepared from P2-P6 wild-type mice. Under control conditions, in slices cut using ACSF as a slicing medium, brief application of GABA evoked a transient increase in the frequency of APs from $0.02 \pm$ $0.01 \mathrm{~s}^{-1}$ baseline activity to $11.95 \pm 1.43 \mathrm{~s}^{-1}(n=23$ cells; P2-P5; $p=1.2 \cdot 10^{-7}$; paired-sample Wilcoxon signed-rank test; Fig. $8 A$ ). Bath application of urethane at $10 \mathrm{~mm}$, matching the drug concentration achieved in vivo at doses of $0.5-1.0 \mathrm{~g} / \mathrm{kg}$ (Sceniak and MacIver, 2006) used in the present study, reduced the baseline activity to $0.01 \pm 0.01 \mathrm{~s}^{-1}(n=21$ cells; P2-P5; $p=5.7$. $10^{-14}$; Mann-Whitney test), which is in keeping with a depressant action of urethane on neuronal firing (Mercer et al., 1978; Sceniak and MacIver, 2006). However, GABA application in the presence of urethane still increased neuronal firing, reaching a frequency of $23.66 \pm 4.97 \mathrm{~s}^{-1}$ during responses $(n=21$ cells; $\mathrm{P} 2-\mathrm{P} 5 ; p=4.8 \cdot 10^{-7}$; paired-sample Wilcoxon signed-rank test; Fig. $8 A, D)$. Moreover, the excitatory effect of GABA estimated as the number of APs during a GABA response, normalized to the baseline activity, showed an increase in the presence of urethane from $797 \pm 95$ to $3379 \pm 709\left(n=21\right.$ cells; P2-P5; $p=1.1 \cdot 10^{-8}$; Mann-Whitney test; Fig. $8 D$ ). The excitatory action of GABA was completely abolished following bath application of the NKCC1 antagonist bumetanide ( $10 \mu \mathrm{M} ; n=17$ cells; Fig. $8 A, D)$.

The excitatory effect of GABA also persisted (1) in slices prepared using a choline-based solution, where GABA application induced a $57 \pm 6$-fold increase in firing of neocortical cells $(n=$ $11 ; p=4.9 \cdot 10^{-4}$; paired-sample Wilcoxon signed-rank test; Fig. $8 B, E)$, (2) during slice perfusion with $\mathrm{mACSF}$ with an electrolyte composition better matching the in vivo situation $\left(1.5 \mathrm{mM} \mathrm{CaCl}_{2}\right.$, $1 \mathrm{mM} \mathrm{MgCl}_{2}, 3 \mathrm{~mm} \mathrm{KCl}$; Nicholson et al., 1976; Mody and Heinemann, 1986; Amzica et al., 2002; Windmuller et al., 2005; $190 \pm 22$-fold increase in GABA-evoked firing; $n=11$ cells; $p=$ $4.9 \cdot 10^{-4}$; paired-sample Wilcoxon signed-rank test; Fig. $8 B, E$ ), (3) upon heating ACSF in the recording chamber to $36^{\circ} \mathrm{C}(125 \pm$ 20 -fold GABA-evoked increase in firing; $n=13$ cells; $p=1.2$. $10^{-4}$; paired-sample Wilcoxon signed-rank test; Fig. 8C,F).

\section{Discussion}

We report a novel technique for the investigation of excitatory/inhibitory actions of GABA on principal neurons through an assessment of the changes in the frequency of Glu-EPSCs evoked by photostimulation of interneurons expressing ChR2. Using this technique, we show that in cortical slices in vitro, the changes in EPSC frequency evoked by photostimulation of interneurons switch from an increase at P2-P8 to a decrease at $\mathrm{P} 9-\mathrm{P} 15$, which is in keeping with the excitatory-to-inhibitory switch in actions of GABA on the principal cells described using other techniques. Using a similar approach in the urethane-anesthetized animals in vivo, we also show that in contrast to this developmental switch observed in vitro, photostimulation of interneurons uniformly reduces EPSC frequency in $\mathrm{P} 3-\mathrm{P} 9$ animals in vivo. 
A
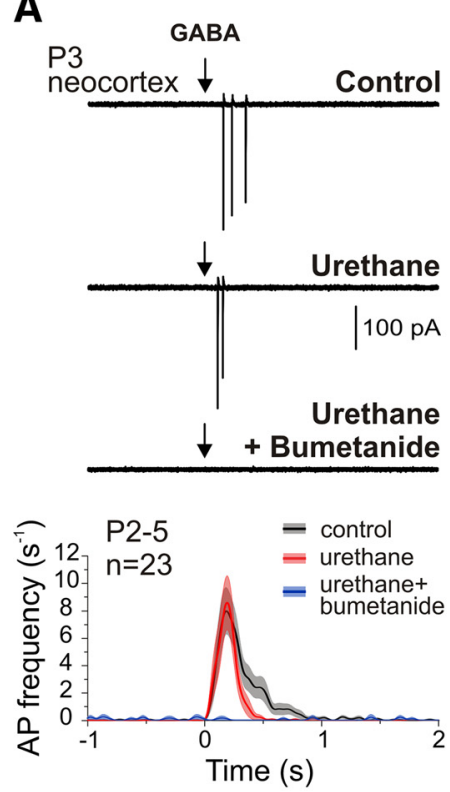

D

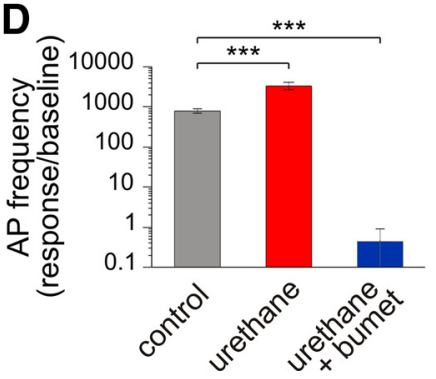

B
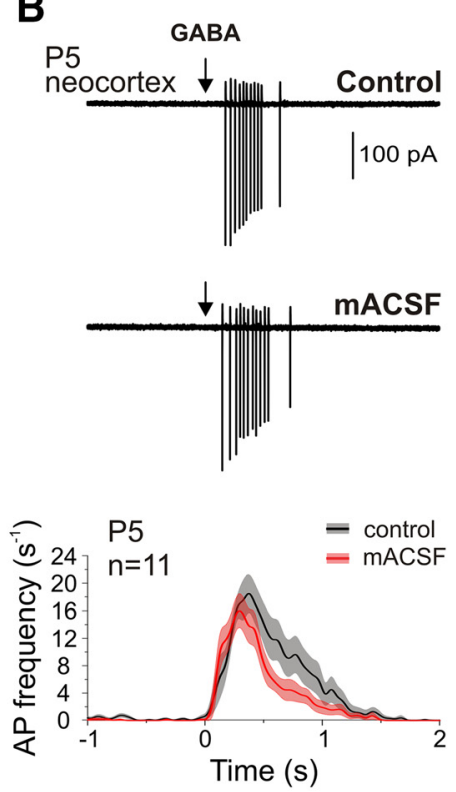

E

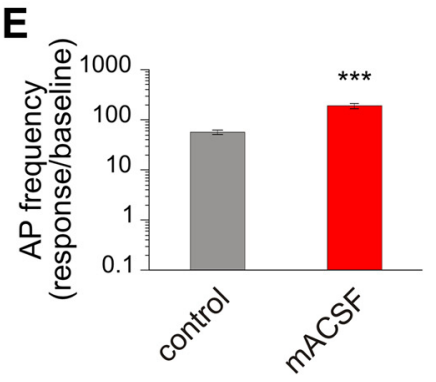

C
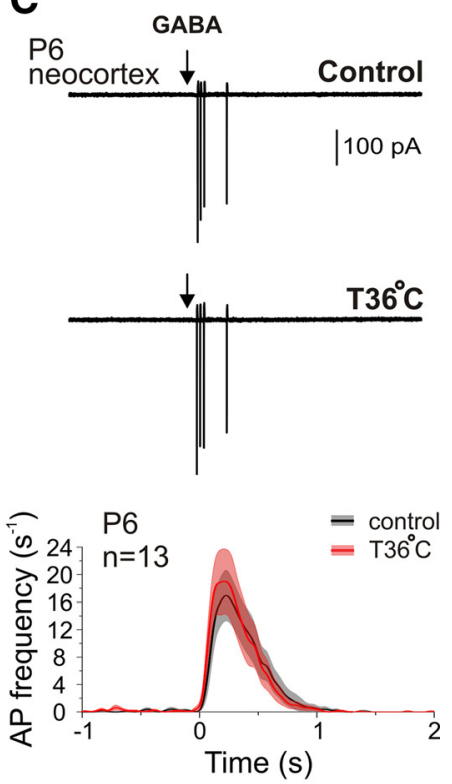

$F$

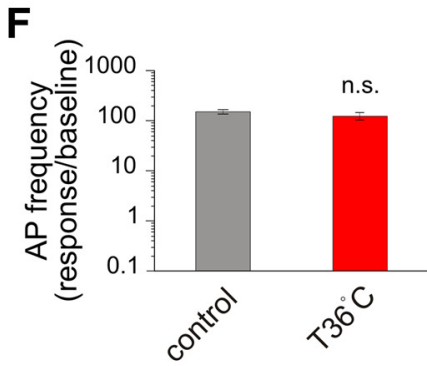

Figure 8. Effects of various experimental conditions on the excitatory GABA actions in vitro. $\boldsymbol{A}-\boldsymbol{C}$, Example traces of responses evoked by local GABA puff application (arrow) under control conditions, in the presence of bath-applied urethane $(10 \mathrm{~mm})$, and during coapplication of urethane and $10 \mu \mathrm{m}$ NKCC 1 antagonist bumetanide $(\boldsymbol{A})$, in the presence of the $\mathrm{mACSF}(\boldsymbol{B})$, and after heating the ACSF in the recording chamber to $36^{\circ} \mathrm{C}(\mathbf{C})$. Averaged plots of AP frequency change in response to GABA puff application in P2-P6 wild-type mouse cortical slices fitted with basis spline function are shown below the traces. The shaded area around each curve shows SE bands. $\boldsymbol{D}-\boldsymbol{F}$, Pooled data on AP frequency during responses to puff application normalized to the baseline frequency obtained from P2-P6 wild-type mouse cortical slices under different experimental conditions. The control recordings were made in bath-applied ACSF from slices prepared using ACSF as slicing medium $(\boldsymbol{A}, \boldsymbol{D})$, in bath-applied ACSF from slices prepared using the choline-based solution as slicing medium $(\boldsymbol{B}, \boldsymbol{E})$, and in bath-applied $\mathrm{mACSF}$ from slices prepared using the choline-based solution as slicing medium $(\boldsymbol{C}, \boldsymbol{F}) .{ }^{* * *} p<0.001 ;$ n.s., $p \geq 0.05$.

To assess the excitatory/inhibitory actions of GABA on principal neurons, we measured changes in the frequency of glutamatergic currents in response to photostimulation of ChR2expressing GABAergic neurons. The rationale of this approach is based on an assumption that if GABA excites principal neurons, photorelease of GABA from interneurons will result in increased firing of principal cells, leading to an increase of EPSC frequency in their target neurons, whereas inhibitory GABA action will result in a decrease in EPSC frequency. Previously Owens and colleagues (1999) used a similar readout of GABA actions by showing that application of the GABA(A) agonist evokes an increase in spontaneous PSC frequency, indicating excitatory GABA actions in P3-P4 rat neocortical slices. In agreement with these results, we also found that activation of $G A B A(A)$ receptors by GABA released from interneurons in response to photostimulation evokes an increase in the frequency of spontaneous EPSCs in P2-P8 animals in vitro. Our results are also in agreement with the developmental excitatory-to-inhibitory switch in the actions of GABA on cortical neurons in slices in vitro occurring at the end of the first postnatal week as a result of the progressive negative shift in the reversal potential of the GABAergic responses (BenAri et al., 1989). With our approach, we found that the switch in GABA actions occurs in the mouse neocortex and hippocampus at $\mathrm{P} 8-\mathrm{P} 9$, and this value is within the estimates obtained using other noninvasive techniques (Tyzio et al., 2007, 2008).

The assessment of excitatory/inhibitory actions of GABA through photostimulation of interneurons described in the present study has several important advantages over existing techniques and has a potential for improvement. First, it enables the avoidance of pharmacological isolation of GABA(A) receptormediated responses, which is conventionally used during electrical stimulation, and thus the avoidance of potential direct or indirect (through a modification of activity) effects of drugs on the reversal potential of the GABAergic responses. Second, photostimulation does not produce any mechanical disturbance in the tissue, which occurs in the case of puff application of $\mathrm{GABA}(\mathrm{A})$ receptor agonists and provides physiological stimulation of $G A B A(A)$ receptors by interneurons that may differ from the responses evoked by the agonists. For example, it has been shown that application of the GABA(A) receptor agonist muscimol results in a contraction of target muscles in the immature $C$. elegans, whereas the response evoked by endogenous GABA(A) receptor activation through photostimulation of ChR2-expressing interneurons produces the opposite effect, an inhibition and paralysis of muscles (Han et al., 2015). Finally, this approach has a potential in the exploration of GABA actions in deep brain 
structures having both the optical fiber and recording system in one patch pipette.

While our results confirm the excitatory actions of GABA on principal neurons in cortical slices during the early postnatal period, we failed to find any evidence of excitatory actions of GABA in the cortex of neonatal rat pups in vivo. Instead, we observed a decrease in EPSC frequency in response to photostimulation of GABAergic neurons in P3-P9 mice. While our assessment of GABAergic actions is indirect, a parsimonious explanation of the reduction in EPSC frequency during photostimulation of GABAergic neurons is that GABA exerts an inhibitory action on glutamatergic cells. Actually, very few previous studies have addressed the question of whether GABA exerts excitatory actions in the developing mammalian cortex in vivo. Using cellattached recordings and calcium imaging, it has been shown that neither application of the GABA(A) receptor agonist muscimol nor synaptic stimulation of $\mathrm{GABA}(\mathrm{A})$ receptors evokes $\mathrm{APs}$ or calcium transients in neocortical neurons from neonatal P3-P4 mice (Kirmse et al., 2015). Pharmacological characterization of the early network-driven bursts also indicated inhibitory actions of GABA at the network level (Minlebaev et al., 2007; Kirmse et al., 2015). At the same time, depolarizing actions of GABA on immature cortical neurons in vivo were revealed using cellattached recordings of GABA(A) channels (Tyzio et al., 2008) or cell-attached current-clamp recordings and calcium imaging in the presence of the L-type calcium-channel modulator BayK 8644, which negatively shifts their threshold (Kirmse et al., 2015). Together, these data suggest that while GABA depolarizes neonatal cortical neurons in vivo, this depolarization does not attain the AP threshold, and that GABA exerts essentially inhibitory network actions through the shunting mechanism, similar to the presynaptic shunting inhibition by depolarizing GABA at the axon terminals (Willis, 2006).

The reasons for a difference in the network effects of GABA during the early stages in vitro (excitation) and in vivo (inhibition) remain at present unknown. Previously, it has been suggested that ketone bodies that constitute an important energy source for the immature brain tissue are involved in modulation of the GABA actions that could potentially account for the inhibitory network actions of GABA in vivo (Rheims et al., 2009). This hypothesis has not been confirmed in more recent studies, however (Kirmse et al., 2010; Ruusuvuori et al., 2010; Tyzio et al., 2011). Alternatively, traumatic injury during slice preparation induces a secondary excitatory GABA phenotype in neurons located at the slice surface during the second postnatal week (Dzhala et al., 2012). However, during the first postnatal week, GABA exerts excitatory actions through the entire slice depth, and therefore excitatory GABA actions during the early postnatal period do not involve traumatic injury (Valeeva et al., 2013), unless the effects of trauma extend through the entire slice as a consequence of reduced mechanical stability of the immature tissue. Bicarbonate-mediated chloride and potassium shifts, which underlie excitatory GABA actions during massive activation of GABA(A) receptors in adult neurons, are also unlikely contributors to the excitatory GABA actions on the immature neurons in vitro as this mechanism does not operate before P12, at a time when expression of carbonic anhydrase VII shows a steep increase (Rivera et al., 2005). In the present study, we also ruled out several other potential factors that could contribute to a difference in GABA actions in vivo and in vitro, including urethane actions, electrolyte composition of the extracellular solution, use of choline in the slicing medium, and tempera- ture. Another potential factor that may have a role in explaining differences in GABA actions in vivo and in vitro is the difference in resting membrane potential, as suggested by the almost fivefold higher frequency of spontaneous EPSCs observed in vivo. This difference might induce a different functional response to the same degree of membrane depolarization in pyramidal cells, and result in reduced AP firing and glutamate release in vivo versus increased AP generation in vitro.

In conclusion, we have combined electrophysiological and optogenetic approaches to suggest a tool for the investigation of the excitatory/inhibitory GABA actions that may be useful in studies addressing GABA actions in the neuronal network during development, under pathological conditions (epilepsy, neuronal trauma, pain), and in other cases where an assessment of GABA actions is required. However, we specify that our results do not disprove the hypothesis of the excitatory GABA during development. Our conclusion on the inhibitory effects of GABA in vivo is limited to $\geq \mathrm{P} 3$ animals and it is conceivable that GABA exerts excitatory actions at earlier developmental stages. Also, while we have shown that excitatory actions of GABA in neonatal brain slices persist in the presence of urethane, the effects of the anesthetics may be more complex in vivo, involving indirect changes in hormonal status and cortical states and therefore our conclusions are limited to the condition of anesthesia, thus requiring further verification in nonanesthetized animals. Finally, the test we are proposing to assess GABA actions provides only a global estimate. The actions of GABA may vary between cells, depending on their type and age, and also within different cell compartments.

\section{References}

Amzica F, Massimini M, Manfridi A (2002) Spatial buffering during slow and paroxysmal sleep oscillations in cortical networks of glial cells in vivo. J Neurosci 22:1042-1053. Medline

Astorga G, Bao J, Marty A, Augustine GJ, Franconville R, Jalil A, Bradley J, Llano I (2015) An excitatory GABA loop operating in vivo. Front Cell Neurosci 9:275. CrossRef Medline

Atallah BV, Bruns W, Carandini M, Scanziani M (2012) Parvalbuminexpressing interneurons linearly transform cortical responses to visual stimuli. Neuron 73:159-170. CrossRef Medline

Ben-Ari Y, Cherubini E, Corradetti R, Gaiarsa JL (1989) Giant synaptic potentials in immature rat CA3 hippocampal neurones. J Physiol 416: 303-325. CrossRef Medline

Ben-Ari Y, Gaiarsa JL, Tyzio R, Khazipov R (2007) GABA: a pioneer transmitter that excites immature neurons and generates primitive oscillations. Physiol Rev 87:1215-1284. CrossRef Medline

Cherubini E, Gaiarsa JL, Ben-Ari Y (1991) GABA: an excitatory transmitter in early postnatal life. Trends Neurosci 14:515-519. CrossRef Medline

Chiu WT, Lin CM, Tsai TC, Wu CW, Tsai CL, Lin SH, Chen JJ (2014) Real-time electrochemical recording of dopamine release under optogenetic stimulation. PLoS One 9:e89293. CrossRef Medline

Cohen I, Navarro V, Clemenceau S, Baulac M, Miles R (2002) On the origin of interictal activity in human temporal lobe epilepsy in vitro. Science 298:1418-1421. CrossRef Medline

Curtis DR, Duggan AW, Felix D, Johnston GA (1970) GABA, bicuculline and central inhibition. Nature 226:1222-1224. CrossRef Medline

Dine J, Kühne C, Deussing JM, Eder M (2014) Optogenetic evocation of field IPSPs in hippocampal slices: a simple and reliable approach for studying pharmacological effects on GABAA and GABAB receptormediated neurotransmission. Front Cell Neurosci 8:2. Medline

Dzhala V, Valeeva G, Glykys J, Khazipov R, Staley K (2012) Traumatic alterations in GABA signaling disrupt hippocampal network activity in the developing brain. J Neurosci 32:4017-4031. CrossRef Medline

Farrant M, Kaila K (2007) The cellular, molecular and ionic basis of GABA(A) receptor signalling. Prog Brain Res 160:59-87. CrossRef Medline

Feldbauer K, Zimmermann D, Pintschovius V, Spitz J, Bamann C, Bamberg E 
(2009) Channelrhodopsin-2 is a leaky proton pump. Proc Natl Acad Sci U S A 106:12317-12322. CrossRef Medline

Freund TF, Buzsáki G (1996) Interneurons of the hippocampus. Hippocampus 6:347-470. Medline

Fu LY, van den Pol AN (2007) GABA excitation in mouse hilar neuropeptide Y neurons. J Physiol 579:445-464. CrossRef Medline

Gradmann D, Berndt A, Schneider F, Hegemann P (2011) Rectification of the channelrhodopsin early conductance. Biophys J 101:1057-1068. CrossRef Medline

Gulledge AT, Stuart GJ (2003) Excitatory actions of GABA in the cortex. Neuron 37:299-309. CrossRef Medline

Han B, Bellemer A, Koelle MR (2015) An evolutionarily conserved switch in response to GABA affects development and behavior of the locomotor circuit of Caenorhabditis elegans. Genetics 199:1159-1172. CrossRef Medline

Kätzel D, Zemelman BV, Buetfering C, Wölfel M, Miesenböck G (2011) The columnar and laminar organization of inhibitory connections to neocortical excitatory cells. Nat Neurosci 14:100-107. CrossRef Medline

Kaila K, Ruusuvuori E, Seja P, Voipio J, Puskarjov M (2014a) GABA actions and ionic plasticity in epilepsy. Curr Opin Neurobiol 26:34-41. CrossRef Medline

Kaila K, Price TJ, Payne JA, Puskarjov M, Voipio J (2014b) Cation-chloride cotransporters in neuronal development, plasticity and disease. Nat Rev Neurosci 15:637-654. CrossRef Medline

Katz Y, Yizhar O, Staiger J, Lampl I (2013) Optopatcher-an electrode holder for simultaneous intracellular patch-clamp recording and optical manipulation. J Neurosci Methods 214:113-117. CrossRef Medline

Khalilov I, Holmes GL, Ben-Ari Y (2003) In vitro formation of a secondary epileptogenic mirror focus by interhippocampal propagation of seizures. Nat Neurosci 6:1079-1085. CrossRef Medline

Khalilov I, Minlebaev M, Mukhtarov M, Khazipov R (2015) Dynamic changes from depolarizing to hyperpolarizing GABAergic actions during giant depolarizing potentials in the neonatal rat hippocampus. J Neurosci 35:12635-12642. CrossRef Medline

Khazipov R, Valeeva G, Khalilov I (2015) Depolarizing GABA and developmental epilepsies. CNS Neurosci Ther 21:83-91. CrossRef Medline

Kirmse K, Witte OW, Holthoff K (2010) GABA depolarizes immature neocortical neurons in the presence of the ketone body $\beta$-hydroxybutyrate. J Neurosci 30:16002-16007. CrossRef Medline

Kirmse K, Kummer M, Kovalchuk Y, Witte OW, Garaschuk O, Holthoff K (2015) GABA depolarizes immature neurons and inhibits network activity in the neonatal neocortex in vivo. Nat Commun 6:7750. CrossRef Medline

Krnjevic K, Phillis JW (1963) Iontophoretic studies of neurones in the mammalian cerebral cortex. J Physiol 165:274-304. CrossRef Medline

Ladas TP, Chiang CC, Gonzalez-Reyes LE, Nowak T, Durand DM (2015) Seizure reduction through interneuron-mediated entrainment using low frequency optical stimulation. Exp Neurol 269:120-132. CrossRef Medline

Ledri M, Madsen MG, Nikitidou L, Kirik D, Kokaia M (2014) Global optogenetic activation of inhibitory interneurons during epileptiform activity. J Neurosci 34:3364-3377. CrossRef Medline

Lee SH, Kwan AC, Zhang S, Phoumthipphavong V, Flannery JG, Masmanidis SC, Taniguchi H, Huang ZJ, Zhang F, Boyden ES, Deisseroth K, Dan Y (2012) Activation of specific interneurons improves V1 feature selectivity and visual perception. Nature 488:379-383. CrossRef Medline

Lovett-Barron M, Turi GF, Kaifosh P, Lee PH, Bolze F, Sun XH, Nicoud JF, Zemelman BV, Sternson SM, Losonczy A (2012) Regulation of neuronal input transformations by tunable dendritic inhibition. Nat Neurosci 15: 423-430, S1-S3. CrossRef Medline

Luna VM, Morozov A (2012) Input-specific excitation of olfactory cortex microcircuits. Front Neural Circuits 6:69. CrossRef Medline

Marissal T, Bonifazi P, Picardo MA, Nardou R, Petit LF, Baude A, Fishell GJ, Ben-Ari Y, Cossart R (2012) Pioneer glutamatergic cells develop into a morpho-functionally distinct population in the juvenile CA3 hippocampus. Nat Commun 3:1316. CrossRef Medline

Mazzuca M, Minlebaev M, Shakirzyanova A, Tyzio R, Taccola G, Janackova S, Gataullina S, Ben-Ari Y, Giniatullin R, Khazipov R (2011) Newborn analgesia mediated by oxytocin during delivery. Front Cell Neurosci 5:3. CrossRef Medline

Mercer LF Jr, Remley NR, Gilman DP (1978) Effects of urethane on hippocampal unit activity in the rat. Brain Res Bull 3:567-570.
Minlebaev M, Ben-Ari Y, Khazipov R (2007) Network mechanisms of spindle-burst oscillations in the neonatal rat barrel cortex in vivo. J Neurophysiol 97:692-700. CrossRef Medline

Minlebaev M, Valeeva G, Tcheremiskine V, Coustillier G, Khazipov R (2013) Cell-attached recordings of responses evoked by photorelease of GABA in the immature cortical neurons. Front Cell Neurosci 7:83. CrossRef Medline

Mitrukhina O, Suchkov D, Khazipov R, Minlebaev M (2015) Imprecise whisker map in the neonatal rat barrel cortex. Cereb Cortex 25:34583467. CrossRef Medline

Mody I, Heinemann U (1986) Laminar profiles of the changes in extracellular calcium concentration induced by repetitive stimulation and excitatory amino acids in the rat dentate gyrus. Neurosci Lett 69:137-142. CrossRef Medline

Moore AK, Wehr M (2013) Parvalbumin-expressing inhibitory interneurons in auditory cortex are well-tuned for frequency. J Neurosci 33: 13713-13723. CrossRef Medline

Nabekura J, Ueno T, Okabe A, Furuta A, Iwaki T, Shimizu-Okabe C, Fukuda A, Akaike N (2002) Reduction of KCC2 expression and GABAA receptor-mediated excitation after in vivo axonal injury. J Neurosci 22: 4412-4417. Medline

Nagel G, Szellas T, Kateriya S, Huhn W, Adeishvili N, Berthold P, Ollig D, Hegemann P, Bamberg E (2003) Channelrhodopsin-2, a directly lightgated cation-selective membrane channel. Proc Natl Acad Sci U S A 100: 13940-13945. CrossRef Medline

Nicholson C, Steinberg R, Stöckle H, Bruggencate GT (1976) Calcium decrease associated with aminopyridine-induced potassium increase in cat cerebellum. Neurosci Lett 3:315-319. CrossRef Medline

Owen SF, Tuncdemir SN, Bader PL, Tirko NN, Fishell G, Tsien RW (2013) Oxytocin enhances hippocampal spike transmission by modulating fastspiking interneurons. Nature 500:458-462. CrossRef Medline

Owens DF, Kriegstein AR (2002) Is there more to GABA than synaptic inhibition? Nat Rev Neurosci 3:715-727. CrossRef Medline

Owens DF, Liu X, Kriegstein AR (1999) Changing properties of GABA(A) receptor-mediated signaling during early neocortical development. J Neurophysiol 82:570-583. Medline

Pfeffer CK, Xue M, He M, Huang ZJ, Scanziani M (2013) Inhibition of inhibition in visual cortex: the logic of connections between molecularly distinct interneurons. Nat Neurosci 16:1068-1076. CrossRef Medline

Price TJ, Cervero F, Gold MS, Hammond DL, Prescott SA (2009) Chloride regulation in the pain pathway. Brain Res Rev 60:149-170. CrossRef Medline

Quattrocolo G, Maccaferri G (2013) Novel GABAergic circuits mediating excitation/inhibition of Cajal-Retzius cells in the developing hippocampus. J Neurosci 33:5486-5498. CrossRef Medline

Rheims S, Holmgren CD, Chazal G, Mulder J, Harkany T, Zilberter T, Zilberter Y (2009) GABA action in immature neocortical neurons directly depends on the availability of ketone bodies. J Neurochem 110:1330-1338. CrossRef Medline

Rivera C, Voipio J, Kaila K (2005) Two developmental switches in GABAergic signalling: the $\mathrm{K}+-\mathrm{Cl}-$ cotransporter $\mathrm{KCC} 2$ and carbonic anhydrase CAVII. J Physiol 562:27-36. CrossRef Medline

Romo-Parra H, Treviño M, Heinemann U, Gutiérrez R (2008) GABA actions in hippocampal area CA3 during postnatal development: differential shift from depolarizing to hyperpolarizing in somatic and dendritic compartments. J Neurophysiol 99:1523-1534. CrossRef Medline

Ruusuvuori E, Kirilkin I, Pandya N, Kaila K (2010) Spontaneous network events driven by depolarizing GABA action in neonatal hippocampal slices are not attributable to deficient mitochondrial energy metabolism. J Neurosci 30:15638-15642. CrossRef Medline

Sachidhanandam S, Sreenivasan V, Kyriakatos A, Kremer Y, Petersen CC (2013) Membrane potential correlates of sensory perception in mouse barrel cortex. Nat Neurosci 16:1671-1677. CrossRef Medline

Sceniak MP, MacIver B (2006) Cellular actions of urethane on rat visual cortical neurons in vitro. J Neurophysiol 95:3865-3874.

Schlingloff D, Káli S, Freund TF, Hájos N, Gulyás A (2014) Mechanisms of sharp wave initiation and ripple generation. J Neurosci 34:11385-11398.

Stark E, Eichler R, Roux L, Fujisawa S, Rotstein HG, Buzsáki G (2013) Inhibition-induced theta resonance in cortical circuits. Neuron 80: 1263-1276. CrossRef Medline

Szabadics J, Varga C, Molnár G, Oláh S, Barzó P, Tamás G (2006) Excitatory 
effect of GABAergic axo-axonic cells in cortical microcircuits. Science 311:233-235. CrossRef Medline

Szydlowski SN, Pollak Dorocic I, Planert H, Carlén M, Meletis K, Silberberg G (2013) Target selectivity of feedforward inhibition by striatal fast-spiking interneurons. J Neurosci 33:1678-1683. CrossRef Medline

Tyzio R, Cossart R, Khalilov I, Minlebaev M, Hübner CA, Represa A, Ben-Ari Y, Khazipov R (2006) Maternal oxytocin triggers a transient inhibitory switch in GABA signaling in the fetal brain during delivery. Science 314: 1788-1792. CrossRef Medline

Tyzio R, Holmes GL, Ben-Ari Y, Khazipov R (2007) Timing of the developmental switch in GABA(A)-mediated signalling from excitation to inhibition in CA3 rat hippocampus using gramicidin perforated patch and extracellular recordings. Epilepsia 48:96-105. CrossRef Medline

Tyzio R, Minlebaev M, Rheims S, Ivanov A, Jorquera I, Holmes GL, Zilberter Y, Ben-Ari Y, Khazipov R (2008) Postnatal changes in somatic gammaaminobutyric acid signalling in the rat hippocampus. Eur J Neurosci 27: 2515-2528. CrossRef Medline

Tyzio R, Allene C, Nardou R, Picardo MA, Yamamoto S, Sivakumaran S, Caiati MD, Rheims S, Minlebaev M, Milh M, Ferré P, Khazipov R, Romette JL, Lorquin J, Cossart R, Khalilov I, Nehlig A, Cherubini E, Ben-Ari Y (2011) Depolarizing actions of GABA in immature neurons depend neither on ketone bodies nor on pyruvate. J Neurosci 31:34-45. CrossRef Medline

Valeeva G, Valiullina F, Khazipov R (2013) Excitatory actions of GABA in the intact neonatal rodent hippocampus in vitro. Front Cell Neurosci 7:20. CrossRef Medline

van den Pol AN, Obrietan K, Chen G (1996) Excitatory actions of GABA after neuronal trauma. J Neurosci 16:4283-4292. Medline

Wang H, Sugiyama Y, Hikima T, Sugano E, Tomita H, Takahashi T, Ishizuka T, Yawo H (2009) Molecular determinants differentiating photocurrent properties of two channelrhodopsins from Chlamydomonas. J Biol Chem 284:5685-5696. CrossRef Medline

Willis WD (2006) John Eccles' studies of spinal cord presynaptic inhibition. Prog Neurobiol 78:189-214. CrossRef Medline

Windmüller O, Lindauer U, Foddis M, Einhäupl KM, Dirnagl U, Heinemann U, Dreier JP (2005) Ion changes in spreading ischaemia induce rat middle cerebral artery constriction in the absence of NO. Brain 128:20422051. CrossRef Medline

Woodruff AR, McGarry LM, Vogels TP, Inan M, Anderson SA, Yuste R (2011) State-dependent function of neocortical chandelier cells. J Neurosci 31:17872-17886. CrossRef Medline 